\title{
NOTE
}

\section{Vibrio tapetis isolated from vesicular skin lesions in Dover sole Solea solea}

\author{
A. M. Declercq ${ }^{1}$, K. Chiers ${ }^{2}$, M. Soetaert ${ }^{2,3}$, A. Lasa $^{4}$, J. L. Romalde ${ }^{4}$, H. Polet $^{3}$, \\ F. Haesebrouck ${ }^{2}$, A. Decostere ${ }^{1, *}$ \\ ${ }^{1}$ Department of Morphology, Faculty of Veterinary Medicine, Ghent University, 9820 Merelbeke, Belgium \\ ${ }^{2}$ Department of Pathology, Bacteriology and Poultry Diseases, Faculty of Veterinary Medicine, Ghent University, \\ 9820 Merelbeke, Belgium \\ ${ }^{3}$ Institute for Agricultural and Fisheries Research (ILVO), Animal Sciences-Fisheries, 8400 Oostende, Belgium \\ ${ }^{4}$ University Santiago de Compostela, Department Microbiology \& Parasitology, CIBUS, Santiago de Compostela 15782, Spain
}

\begin{abstract}
Vibrio tapetis is primarily known as the causative agent for brown ring disease in bivalves, although it has been isolated from cultivated fish during mortalities on farms. Here we describe the first isolation of $V$. tapetis from wild-caught and subsequently captive-held Dover sole Solea solea. Pathological features consisted of multifocal circular greyish-white skin discolourations evolving into vesicular lesions and subsequent ulcerations on the pigmented side. On the non-pigmented side, multiple circular lesions - white at the center and red at the edges were evident. Histological examination of the vesicular lesions revealed dermal fluid-filled spaces, collagen tissue necrosis and a mixed inflammatory infiltrate, with large numbers of small rod-shaped bacteria. In the deep skin lesions, loss of scales and dermal connective tissue, with degeneration and fragmentation of the myofibres bordering the ulceration, were noted. Serotyping, DNA-DNA hybridization and REP- and ERIC-PCR techniques showed that the retrieved isolates displayed a profile similar to the representative strain of genotype/serotype O2 which originally was isolated from carpet-shell clam Venerupis decussata and to which isolates obtained from wedge sole Dicologoglossa cuneata were also closely related.
\end{abstract}

KEY WORDS: Vibrio tapetis $\cdot$ Solea solea $\cdot$ Skin vesicle $\cdot$ Ulcer

\section{INTRODUCTION}

In the North Sea Dover sole Solea solea is mainly caught using beam trawls with tickler chains or a chain matrix. This fishing technique has several disadvantages including seabed disturbance, high discards and high fuel consumption. The most promising alternative, meeting both the fisherman's aspirations and the need for ecological progress, is electro-pulse fishing. Here the tickler chains are replaced by electrodes gliding over the sea floor and inducing electrical pulses, which elicit an upward movement of the fish enabling them to be caught without ploughing the seabed. This leads to a marked decrease in sea floor disturbance, reduces by-catch and halves the fuel consumption. However, electric pulses may result in adverse effects such as dislocated spinal cords and hemorrhaging in the target organisms (Soetaert et al. 2015). It was in this context that an experiment was set up to characterize the impact of electric pulses in sole. Prior to that research, skin pathology including vesicular lesions and ulcerations was noted, which is described in the present study. 


\section{CASE DESCRIPTION}

\section{Animals and housing}

All fish were captured in the North Sea with an $8 \mathrm{~m}$ beam trawl from the research vessels RV 'Belgica' and RV 'Simon Stevin', during 4 sea trips: Bay of Thames (December 2011); coast of Ostend, Belgium (August 2013); east coast of England, UK (September 2013); and coast of Ostend, Belgium (September 2013). Only short $( \pm 15 \mathrm{~min})$ fishing hauls were carried out in order to reduce stress and injury caused by the fishing process. On board fishing vessels, the animals were stored in closed containers with continuous seawater flow. Once ashore, only fish in good condition were transferred to housing facilities at the Institute for Agricultural and Fisheries Research (ILVO) in Ostend, Belgium, where the fish varying between 18 and $35 \mathrm{~cm}$ in length were stocked in groups of 4 to 8 animals in polyvinylchloride tanks filled with $350 \mathrm{l}$ of recirculating natural seawater at $15^{\circ} \mathrm{C}$. Sole caught during different sea trips were not mixed. The tanks were supplied by a common fully functional biological filter. A UV filter (Kockney Koi - Yamitsu, Algae Master $30 \mathrm{~W}$ ), extra oxygenation by means of air pumps and a natural light regime were provided. The ammonia and nitrite levels never exceeded 0.05 and $0.01 \mathrm{mg} \mathrm{l}^{-1}$, respectively. For other water-quality parameters, the following values were recorded: $35 \%$ salinity; $6^{\circ}$ carbonate hardness; $\mathrm{pH} 8$; and nitrate $<50 \mathrm{mg} \mathrm{l}^{-1}$. The sole were fed sandworms and mussels twice a week.

\section{Clinical observations}

One week following the introduction of the last group of sole, 1 out of the 20 sole that had been caught during the second sea trip displayed abnormal, agitated swimming behaviour whilst remaining at the water surface. Multifocal deep skin lesions exposing the musculature were noted on the pigmented side. This fish died the next day. At that time, the 4 sole that had been caught during the first sea trip displayed a decrease in appetite. Three days later, 3 of these animals showed multifocal circular greyish-white skin discolourations of up to $2 \mathrm{~cm}$ in diameter, evolving into vesicular lesions (Fig. 1) and subsequent ulcerations on the pigmented side within $2 \mathrm{~d}$. Skin remnants were observed floating at the surface of the tank. On the non-pigmented side, multiple circular lesions - white at the center and red at the edges - were evident. Five days after the first

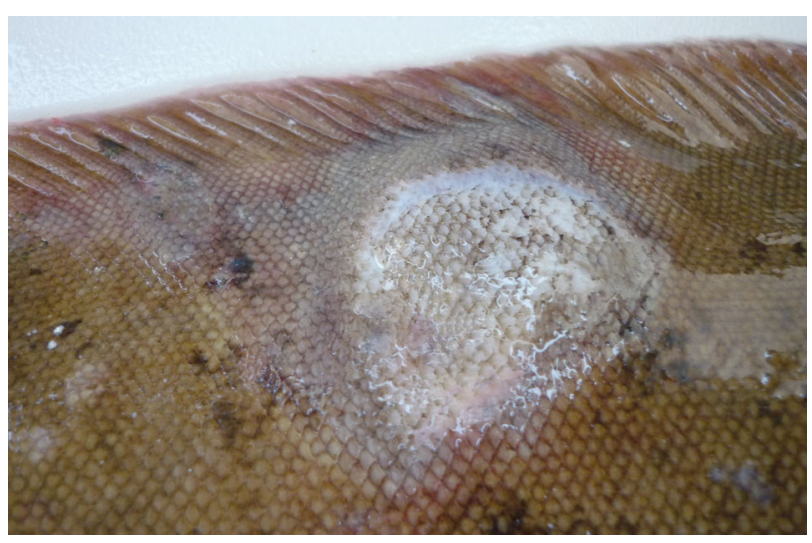

Fig. 1. Solea solea. Subepidermal vesicle on pigmented skin of sole, located ventral to the dorsal fin

observation of skin lesions, 1 of the affected sole died. The other 2 animals were sacrificed using an overdose of a benzocaine solution $(1 \mathrm{~g}$ per $10 \mathrm{ml}$ ethanol). None of the other sole housed in the same circuit, but in different tanks, displayed clinical signs of disease or aberrant behaviour.

\section{Sampling}

Wet mounts were made from the skin and gills for parasitological examination. The content of the vesicular lesions of the 3 affected sole caught during the first sea trip was sampled aseptically for bacteriological and cytological examination. Samples were likewise taken from the edges of the open wounds. Subsequently, a full necropsy of the 2 sacrificed animals was performed. Samples of the liver, spleen and kidney were collected for bacteriological and histological examination. For bacteriological analysis, samples were inoculated onto marine agar plates (Difco) (skin, internal organs) and modified Shieh agar plates (Shieh 1980, Song et al. 1988) to which $2 \%$ sodium chloride had been added (skin). The plates were incubated for $7 \mathrm{~d}$ at $17^{\circ} \mathrm{C}$. For histological analysis, the samples were fixed in $4 \%$ phosphate-buffered formaldehyde for $24 \mathrm{~h}$, dehydrated in an alcohol-xylene series and embedded in paraffin wax. All tissues were sectioned $(8 \mu \mathrm{m})$ and stained with haematoxylin and eosin (H\&E), Ziehl-Neelsen and Giemsa.

\section{Identification and typing of the retrieved isolates}

Four isolates retrieved from 3 different fish specimens were identified by sequencing the 16S-rRNA gene (De Graef et al. 2003). 
The isolates procured from the vesicular content of 1 sole and an open wound in the head region of a second sole were submitted to serotyping, genotyping and DNA-DNA hybridization (DDH) experiments.

For serotyping, bacterial colonies were tentatively identified by a rapid slide agglutination test using antisera raised against different representative strains of Vibrio tapetis ssp. tapetis (CECT $4600^{\mathrm{T}}$ genotype/ serotype O1; GR0202RD genotype/serotype O2) and V. t. ssp. britannicus (CECT $8161^{\mathrm{T}}$ type strain of the subspecies) (Rodríguez et al. 2006, Balboa \& Romalde 2013) and the whole cells or the O-antigens of the isolates from the present study as described by Toranzo et al. (1987).

For DDH experiments, genomic DNA was extracted using the commercially available High Pure PCR Template Preparation kit (Roche) following the manufacturer's protocol. DDH experiments were undertaken between the GR0202RD strain and the sole isolates. DDH experiments were performed with the hydroxyapatite/microtitre plate method (Ziemke et al. 1998) using a hybridization temperature $\left(T_{\mathrm{m}}\right)$ of $60^{\circ} \mathrm{C}$.

For ERIC (enterobacterial repetitive intergenic consensus)-PCR and REP (repetitive extragenic palindromic)-PCR, chromosomal DNA was extracted using the Insta-Gene Matrix (Bio-Rad) as previously described (Romalde et al. 2002). Extracted DNA was used immediately or maintained at $-20^{\circ} \mathrm{C}$ until used for PCR reactions. ERIC-PCR and REP-PCR were carried out with Ready-to-go PCR beads (Amersham Pharmacia Biotech) as described by Rodríguez et al. (2006). These commercial beads have been optimized for PCR reactions and contain buffer, nucleotides and Taq DNA polymerase; therefore, the only reagents added to the reaction were template DNA $(1 \mu \mathrm{l})$, primers (100 pmol each) and water to complete a volume of $25 \mu$ l. The ERIC and REP primers used in this study have previously been described in detail (Versalovic et al. 1994).

\section{RESULTS}

No parasite infestations in the gill and skin samples were noted.

Cytological examination of the vesicular fluid revealed numerous small rod-shaped bacteria of up to $1.5 \mu \mathrm{m}$ in length in a proteinaceous background.

A cotton-tipped applicator inserted under the wound edges could be advanced without meeting any resistance, undermining the adjacent tissue. The overlying skin could easily be removed, exposing the underlying affected muscle (Fig. 2). Following $48 \mathrm{~h}$ of incubation at $17^{\circ} \mathrm{C}$ the bacteriological media inoculated with the samples of vesicular lesions and the liver of 1 sole showed an abundant culture of greyish-white colonies with smooth edges. This colony type was also predominantly present on the plates that were inoculated with the samples from open wounds. Sequencing the 16S-rRNA gene led to the identification of Vibrio tapetis with a $99 \%$ sequence homology.

In DDH experiments, sole isolates showed levels of DNA relatedness of between 85 and $93 \%$ with the representative strain of the $\mathrm{O} 2$ genotype of $V$. tapetis defined by Rodríguez et al. (2006), confirming that they belong to the species $V$. tapetis.

In the rapid slide agglutination tests, whole cells from sole isolates showed cross-reactivity with all the sera against different representative strains of $V$. tapetis, including subspecies $V$. t. tapetis strains CECT $4600^{\mathrm{T}}$ (genotype/serotype O1) and GR0202RD (genotype/serotype O2), as well as with the sera against the representative strain of subspecies $V . t$. britannicus (CECT $8161^{\mathrm{T}}$ ). However, when O-antigens of the sole isolates were employed, a strong reaction was obtained only with the sera obtained against strain GR0202RD. In the genotyping experiments by REP-and ERIC-PCR techniques, similar results were obtained, with the sole isolates displaying a profile somewhat similar, although not identical, to the representative strain GR0202RD (genotype/serotype O2) (Fig. 3).

Upon histological examination, the vesicular lesions revealed dermal fluid-filled spaces with collagen necrosis and mixed inflammatory infiltrates.

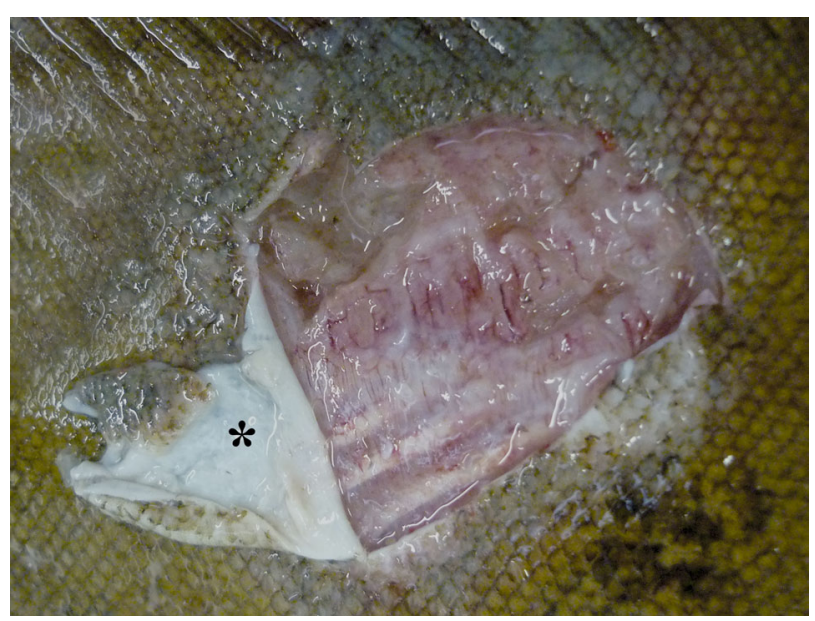

Fig. 2. Solea solea. Exposed underlying affected muscle following removal of overlying skin $\left({ }^{*}\right)$ from a vesicle of sole 

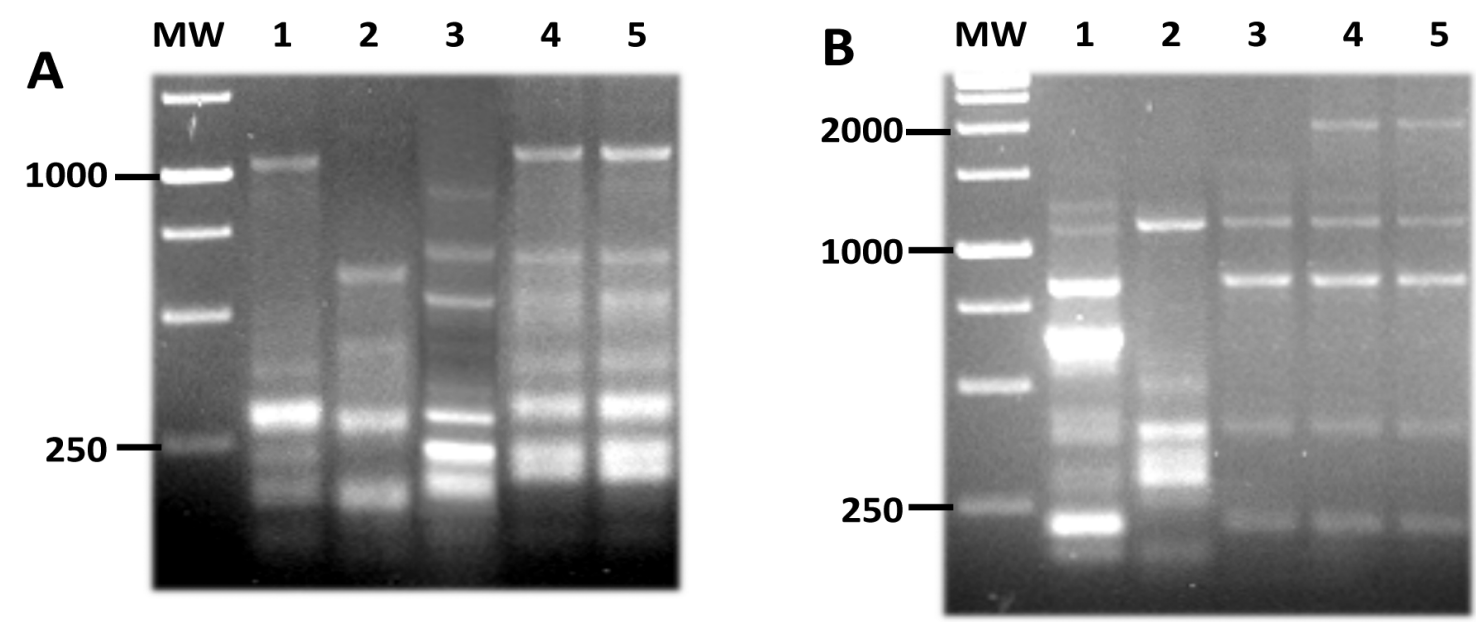

Fig. 3. DNA fingerprints obtained by (A) REP (repetitive extragenic palindromic)-PCR and (B) ERIC (enterobacterial repetitive intergenic consensus)-PCR techniques for Vibrio tapetis strains. MW: molecular weight marker (GeneRulerTM 1 kb DNA Ladder, Fermentas); 1: CECT4600 ${ }^{\mathrm{T}}$ 2: CECT 8161 ${ }^{\mathrm{T}}$; 3: GR0202RD; 4: Sole 1A (Solea solea); 5: Sole 1B. The molecular sizes (in base pairs) are indicated on the left

Large numbers of small rod-shaped bacteria, up to $1.5 \mu \mathrm{m}$ in length, were present in the vesicle. A mild bacterial invasion was found in the underlying connective tissue with interstitial mononuclear infiltration. In the deep skin lesions, a loss of scales and an abrupt transition between epidermis and ulcerated skin was evident, with complete necrosis of dermal connective tissue (Fig. 4). This ulceration was welldelineated by granulation tissue infiltrated with large numbers of mononuclear cells and moderate numbers of neutrophils, as well as numerous bacteria with different morphologies. The myofibers bordering the ulceration were degenerative and fragmented. In between underlying superficial and deep muscle layers, oedema occurred. Lesions were not observed in samples of liver, spleen, or kidney. Acidfast bacteria could not be demonstrated using ZiehlNeelsen staining.

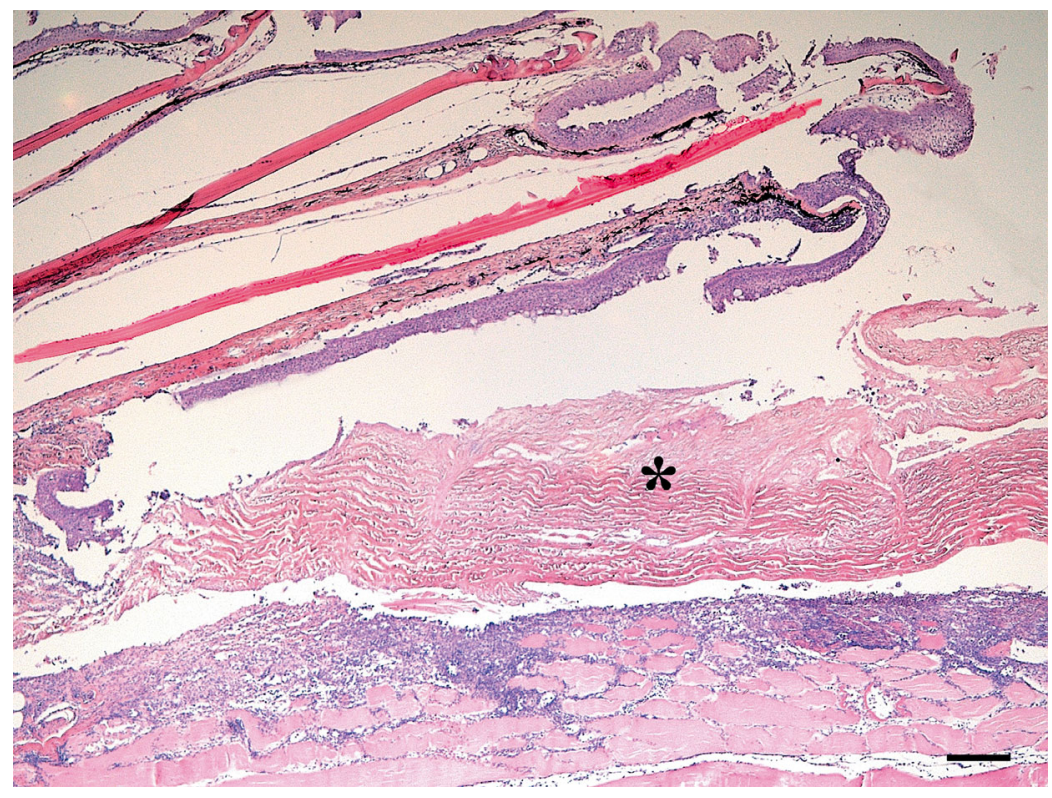

Fig. 4. Solea solea. Light micrograph of the edge of a vesicle, demonstrating necrotic dermal tissue $\left({ }^{*}\right)$ bordered by overlying intact epidermis and underlying degenerated muscle. Hematoxylin \& eosin staining. Scale bar $=200 \mu \mathrm{m}$

\section{DISCUSSION}

Vibrio tapetis (Borrego et al. 1996) was originally isolated in 1990 in Landeda (France). Although the bacterium is primarily known as the causative agent of brown ring disease in bivalves (Paillard et al. 1994, Paillard 2004), it has already been isolated from cultivated fish, namely corkwing wrasse Symphodus melops in Norway (Jensen et al. 2003), Atlantic halibut Hipoglossus hipoglossus in Scotland, UK (Reid et al. 2003), and wedge sole Dicologoglossa cuneata in Spain (López et al. 2011), during mortality episodes on farms. This report describes the first isolation of $V$. tapetis from wild-caught and, subsequently, captive-held Dover sole. V. tapetis was retrieved from the fluid content of vesicles, as well as from open wounds 
resulting from mechanical breakage of vesicular lesions. Likewise, López et al. (2011) recovered this agent from external lesions, more specifically from ulcers. However, no vesicular lesions were conspicuously present as in the affected sole of this study. These large fluid-filled vesicles are, as far as we know, a rarely observed feature in skin pathology of teleost fish. Vesicle formation has been described as a 'winter ulcer' in Atlantic salmon Salmo salar and was suggested to be a result of vascular thrombosis of dermal vessels. These vesicles are then mechanically disrupted by breaking the epidermis during netting and handling the fish (Salte et al. 1994). Lunder et al. (1995) provided evidence that winter ulcers are caused by infection with a Vibriolike bacterium.

The actual pathogenic significance of $V$. tapetis in fish is yet to be clarified, with speculations on its pathogenic nature still prevailing, while questions on the environmental and host-related factors determining disease also remain unanswered. Indeed, in wedge sole and Atlantic halibut, researchers were unable to induce disease in virulence assays (Reid et al. 2003, López et al. 2011). This is in contrast to corkwing wrasse, where the retrieved isolate did prove to be pathogenic for this fish species. In the current study, the sole were kept under favourable conditions in the laboratory. Nevertheless, animals that had already been present in the facilities for almost 2 yr developed skin lesions and were severely affected. This, taken together with a disease onset of $10 \mathrm{~d}$ following introduction of the last sole group, makes it tempting to speculate on the possible role of the newly retrieved sole in the transmission of $V$. tapetis. According to this hypothesis, the latter animals may act as clinically healthy carriers and introduce the agent to a possibly naive sole population. Or, a second hypothesis is that $V$. tapetis was introduced to the tank system via live feed, i.e. mussels or sandworms. However, currently, these lines of reasoning have been insufficiently substantiated and warrant further research.

Besides sole, sea bass Dicentrarchus labrax, European plaice Pleuronectes platessa and dogshark Squalus acanthias were also housed in the tanks. However, these animals did not display clinical signs of the disease or abnormal behaviour (data not shown). Bergh \& Samuelsen (2007) also demonstrated a species-specific susceptibility to $V$. tapetis; in their study corkwing wrasse succumbed to an injection challenge, in contrast to goldsinny wrasse Ctenolabrus rupestis and Atlantic salmon Salmo salar which did not.
According to their REP- and ERIC-PCR profiles (López et al. 2011), the possibility of clonality for the sole isolates cannot be ruled out, and additional studies would be needed to confirm such a hypothesis and its epidemiological implications. On the other hand, the 2 sole isolates displayed a similar profile, although not identical, to the representative strain GR0202RD (genotype/serotype O2), which was originally isolated in 1996 in Galicia from carpet-shell clam Venerupis decussata and to which some isolates obtained in 2005 from wedge sole Dicologoglossa cuneata were closely related. It would be interesting to further compare the sole isolates retrieved in this research with the Spanish wedge sole strains.

In conclusion, this case study is the first report of the isolation of $V$. tapetis from skin vesicles and ulcerations in Dover sole. This agent may have played a role in the development of skin lesions. However, further studies are needed as any pathological associations between the noted lesions and the above agent are currently fairly speculative.

Acknowledgements. This research was supported by a $\mathrm{PhD}$ grant from the Institute for the Promotion of Innovation by Science and Technology in Flanders (IWT-Vlaanderen). Additional support was given by the Flemish Scientific Institute for Agricultural and Fisheries Research (ILVO) and the European Fisheries Fund (EVF). The supply of wild animals was facilitated by Flanders Marine Institute (VLIZ) and the crews of the RV 'Simon Stevin' and RV 'Belgica'. We thank David Vuylsteke for his assistance in taking care of the animals and Christian Puttevils and Delphine Ameye for embedding and processing the samples. Finally, we gratefully acknowledge Prof. Dr. P. Simoens for critically reviewing the manuscript.

\section{LITERATURE CITED}

Balboa S, Romalde JL (2013) Multilocus sequence analysis of Vibrio tapetis, the causative agent of brown ring disease: description of Vibrio tapetis subsp. britannicus subsp. nov. Syst Appl Microbiol 36:183-187

Bergh O, Samuelsen OB (2007) Susceptibility of corkwing wrasse Symphodus melops, goldsinny wrasse Ctenolabrus rupestis, and Atlantic salmon Salmo salar smolt, to experimental challenge with Vibrio tapetis and Vibrio splendidus isolated from corkwing wrasse. Aquacult Int 15:11-18

Borrego JJ, Castro D, Luque A, Paillard C, Maes P, Garcia MT, Ventosa A (1996) Vibrio tapetis sp. nov., the causative agent of the brown ring disease affecting cultured clams. Int J Syst Bacteriol 46:480-484

$>$ De Graef EM, Devriese LA, Vancanneyt M, Baele M and others (2003) Description of Enterococcus canis sp. nov. from dogs and reclassification of Enterococcus porcinus Teixeira et al. 2001 as a junior synonym of Enterococcus villorum Vancanneyt et al. 2001. Int J Syst Evol Microbiol 53:1069-1074 
Jensen S, Samuelsen OB, Andersen K, Torkildsen L and others (2003) Characterization of strains of Vibrio splendidus and V. tapetis isolated from corkwing wrasse Symphodus melops suffering vibriosis. Dis Aquat Org 53: 25-31

López JR, Balboa S, Núñez S, de la Roca E and others (2011) Characterization of Vibrio tapetis strains isolated from diseased cultured wedge sole (Dicologoglossa cuneata Moreau). Res Vet Sci 90:189-195

Lunder T, Evensen Ø, Holstad G, Håstein T (1995) 'Winter ulcer' in the Atlantic salmon Salmo salar. Pathological and bacteriological investigations and transmission experiments. Dis Aquat Org 23:39-49

Paillard C (2004) A short-review of brown ring disease, a vibriosis affecting clams, Ruditapes philippinarum and Ruditapes decussatus. Aquat Living Resour 17:467-475

Paillard C, Maes P, Oubella R (1994) Brown ring disease in clams. Annu Rev Fish Dis 4:219-240

Reid HI, Duncan HL, Laidler LA, Hunter D, Birkbeck TH (2003) Isolation of Vibrio tapetis from cultivated Atlantic halibut (Hippoglossus hippoglossus L.). Aquaculture 221: 65-74

Rodríguez JM, López-Romalde S, Beaz R, Alonso MC, Castro D, Romalde JL (2006) Molecular fingerprinting of Vibrio tapetis strains using three PCR-based methods: ERICPCR, REP-PCR, and RAPD. Dis Aquat Org 69:175-183

Romalde JL, Castro D, Magariños B, López-Cortés L,

Editorial responsibility: David Bruno,

Aberdeen, UK
Borrego JJ (2002) Comparison of ribotyping, randomly amplified polymorphic DNA, and pulsed-ield gel electrophoresis for molecular typing of Vibrio tapetis. Syst Appl Microbiol 25:544-550

Salte R, Rorvik KA, Reed F (1994) Winter ulcers of the skin in Atlantic salmon Salmo salar L.: pathogenesis and possible aetiology. J Fish Dis 17:661-665

Shieh HS (1980) Studies on the nutrition of a fish pathogen, Flexibacter columnaris. Microbios Lett 13:129-133

Soetaert M, Decostere A, Polet H, Verscheuren B, Chiers K (2015) Electrotrawling: a promising alternative fishing technique warranting further exploration. Fish Fish 16: 104-124

Song YL, Fryer JL, Rohovec JS (1988) Comparison of gliding bacteria isolated from fish in North America and other areas of the Pacific rim. Fish Pathol 23:197-202

Toranzo AE, Baya A, Roberson BS, Barja JL, Grimes DJ, Hetrick FM (1987) Specificity of slide agglutination test for detecting bacterial fish pathogens. Aquaculture 61:81-97

Versalovic J, Schneider M, De Bruijn FJ, Lupski JR (1994) Genomic fingerprinting of bacteria using repetitive sequence-based polymerase chain reaction. Methods Mol Cell Biol 5:25-40

Ziemke F, Höfle MG, Lalucat J, Rosselló-Mora R (1998) Reclassification of Shewanella putrefaciens Owen's genomic group II as Shewanella baltica sp. nov. Int J Syst Bacteriol 48:179-186

Submitted: November 17, 2014; Accepted: April 2, 2015 Proofs received from author(s): June 15, 2015 